\begin{tabular}{|l|l|l||}
\hline \multicolumn{2}{|c|}{ PublisherInfo } \\
\hline \hline PublisherName & $:$ & BioMed Central \\
\hline \hline PublisherLocation & $:$ & London \\
\hline \hline PublisherImprintName & $:$ & BioMed Central \\
\hline \hline
\end{tabular}

How ubiquitin silences genes

\begin{tabular}{|l|l|l||}
\hline \multicolumn{2}{|c|}{ ArticleInfo } \\
\hline \hline ArticleID & $:$ & 5015 \\
\hline \hline ArticleDOI & $:$ & $10.1186 /$ gb-spotlight-20041109-01 \\
\hline \hline ArticleCitationID & $:$ & spotlight-20041109-01 \\
\hline \hline ArticleSequenceNumber & $:$ & 78 \\
\hline \hline ArticleCategory & $:$ & Research news \\
\hline ArticleFirstPage & $:$ & 1 \\
\hline \hline ArticleLastPage & $:$ & 3 \\
\hline \hline & & RegistrationDate : 2004-11-9 \\
\hline ArticleHistory & $:$ & OnlineDate \\
\hline \hline ArticleCopyright & $:$ & BioMed Central Ltd2004-11-9 \\
\hline \hline ArticleGrants & $:$ & \\
\hline \hline ArticleContext & $:$ & 130595511 \\
\hline \hline
\end{tabular}




\section{Cathy Holding}

Email: cathyholding@absw.org.uk

A novel mechanism of gene silencing that plays an unexpected role in inactivating the $\mathrm{X}$ chromosome is published in Developmental Cell this week (Dev Cell 2004, 7:663-676). But the paper by Neil Brockdorff's group in London appears several weeks after an almost identical report from Yi Zhang and colleagues from the University of North Carolina at Chapel Hill in Nature.

Brockdorff, at the Medical Research Council's Clinical Sciences Centre, found that ubiquitylation at lysine 119 in histone H2A recruits Polycomb group $(\mathrm{PcG})$ proteins belonging to Polycomb repressor complex 1 (PRC1), known to be involved in gene silencing. The team demonstrated a role for PRC1 proteins and $\mathrm{PcG}$ complexes in genome-wide $\mathrm{H} 2 \mathrm{~A}$ ubiquitylation, thus linking the histone modification to the maintenance of gene silencing. By staining the cells with antibodies, the researchers found monoubiquitylated $\mathrm{H} 2 \mathrm{~A}$ to be highly enriched on the inactive $\mathrm{X}$ chromosome, indicating a role in $\mathrm{X}$ inactivation.

"Ubiquitylation is putting a single 76 amino acid ubiquitin moiety onto a conserved lysine residue in the H2A C-terminal tail," explained Mary Ann Osley, who is based at the Department of Molecular Genetics and Microbiology, University of New Mexico Health Sciences Center and who wrote an accompanying preview for Developmental Cell. "Usually proteins have multiple ubiquitin chains that target them for proteolysis, but histones in general are monoubiquitylated, and that's associated with a signaling or some kind of a structural mark."

The Nobel Prize for Chemistry this year was awarded to pioneering ubiquitin researchers. "Given the significance of polyubiquitylation in protein degradation, monoubiquitylation is the other aspect of ubiqutin," said Zhang, from the University of North Carolina. "There are two main points in the Nature paper. One is the identification of the $\mathrm{E} 3$ ligase responsible for histone $\mathrm{H} 2 \mathrm{~A}$ ubiquitylation. The second important point is to link the function of H2A ubiquitylation to polycomb silencing." Subsequently, his group also demonstrated the role of ubiquitin in X inactivation in a follow-up paper that appeared online in the Journal of Biological Chemistry last month.

"Basically, Brockdorff's paper focused on X inactivation and did not address the role of H2A ubiquitylation in Polycomb silencing," Zhang said. "They did not assay the enzymatic activity directly that may be the reason for citing our Naturepaper."

"It's a co-discovery, sure," Brockdorff told The Scientist, "but if you're writing about the story, he [Zhang] didn't have anything on X inactivation - but he's just had a paper come out online in $J B C$. Now this is something that he's pushed out in a hurry because he heard about our paper."

Brockdorff argued that Zhang's $J B C$ paper, which he described as only a descriptive analysis, contained some errors. "For example, we see this [H2A] ubiquitylation in differentiating cells, and that's quite clear... [but] in his limited analysis, he was finding no evidence of ubiquitylation in differentiated ES cells."

Nevertheless, both groups agree that the findings have significance in cancer research. Another PRC1 protein, Bmil, is an oncogene implicated in the last few years as being critical for regulating stem cell self-renewal versus differentiation, according to Brockdorff. 
"Understanding how this complex works opens up new avenues in terms of intervention - for example, developing new drugs and so on - because we know this is a catalytic mechanism that could be interfered with," Brockdorff said.

\section{References}

1. Dev Cell, [http://www.developmentalcell.com/]

2. Yi Zhang, [http://www.med.unc.edu/ zhangyi/labmembers.htm]

3. Mary Ann Osley, [http://hsc.unm.edu/som/micro/Maryann.html]

4. Pincock S: Ubiquitin researchers win Nobel Genome Biology, October 7, 2004., [http://genomebiology.com/researchnews/default.asp?arx_id=gb-spotlight-20041007-02]

5. Ring 1b-mediated H2A ubiquitination associates with inactive $X$ chromosomes and is involved in Initiation of $\mathrm{X}$-inactivation

This PDF file was created after publication. 